\title{
COMPARATIVE EVALUATION OF DITCH FILTERS WITH PHOSPHORUS SORBING CALCIUM BASED FILTER MATERIALS
}

\author{
Nijolė BASTIENE், Water Resources Engineering Institute, Water and Land Management Faculty, Aleksandras Stulginskis \\ University, Parko g. 6, Vilainiai, LT-58102, Kèdainiai raj., Lithuania, nijole.bastiene@ asu.lt (corresponding author) \\ Valerijus GASIŪNAS, Water Resources Engineering Institute, Water and Land Management Faculty, Aleksandras Stulginskis \\ University, Parko g. 6, Vilainiai, LT-58102, Kèdainiai raj., Lithuania, valerijus.gasiunas@asu.lt
}

The aim of this paper was to evaluate the sorption capacity of calcium based filter materials (Polonite, Filtralite P and Hyttsand) under Lithuanian conditions. The results obtained from 16 months long ditch filters investigations showed that the efficiency of tested filter materials varies from 60 to $30 \%$ on the average. The filter material Polonite was distinguished by highest reduction capacity of phosphorus, slightly less reduction was determined using Hyttsand and the least using Filtralite-P. The monitoring results confirmed that ditch filters have some ability to the retention of phosphorus and water purification. In total, ditch filters adsorbed about 96-208 g total phosphorus (TP) and 20-124 g phosphate phosphorus (PO4-P) during the reporting period (January 2013 - May 2014).

Keywords: agriculture, filter materials, phosphorus, reduction capacity.

\section{INTRODUCTION}

The most important anthropogenic source of nutrients entering the Baltic Sea and causing the eutrophication, are compounds of nitrogen and phosphorus from agricultural sources (HELCOM, 2012). Therefore reducing the pressure of agriculture on the Sea environment is a very important task. The private foundation "Baltic Sea 2020" is aimed to contribute towards turning the negative environmental trend of the Baltic Sea in a positive direction by the year 2020 . This is achieved on concrete measures such as: research, opinion making and active engagement in projects.

It is important that the activities aiming to mitigate adverse impact should not affect to the reduction of production capacity of agriculture. Protective zones, riparian buffer strips and construction of wetlands are measures already in use today, but they are not efficient enough to obtain aspired results of reduced leakage of phosphorus (Abu-Zreig et al., 2003; Braskerud and Hauge, 2008; Hoffmann et al., 2009). In addition, these measures also reduce a significant area of agricultural land and this is a reason why are not always benevolently welcomed by farmers. So there is a need to find the means requiring little space but providing rapid effect. This could be achieved by using filters for removing nutrients from agricultural runoff close to the sources, i.e. in or at the ditches downstream the arable land (Vadas et al., 2007).

There are various types of filter materials from sand to products based on lime or lightweight aggregates that can be used to reduce nutrients and suspended sediments in water (Penn and Bryant, 2006; Ballantine and Tanner, 2010; Falk Øgaard, 2010; Kjaergaard, 2010). Sand filters can reduce particles and particulate-bound phosphorus, but if dissolved phosphorus is to be reduced, a reactive phosphorus-binding material (calcium, iron or aluminium) is needed (Oates, 1998; Bryant et al., 2011). Many of lime-based filter materials such as slag (from steel production), fly ash (from power plants) or calcium-rich shell sand have the ability to chemically bind dissolved phosphorus and can also be used (Dobbie et al. 2009; Kirkkala et al., 2012; Søvik and Kløve, 2005; Shilton et al., 2006). Calcium-based (Ca) and an iron-based $(\mathrm{Fe})$ phosphorus sorbing materials removed substantial amounts of $\mathrm{P}$ from agricultural surface runoff, subsurface runoff, and or wastewaters (Leader et al., 2008; Renman and Renman, 2010).

The efficiency of $\mathrm{P}$ removal depends on the physical and chemical properties of the material. Therefore, materials with a large surface area and high $\mathrm{pH}$ are commonly used for binding and precipitation of the $\mathrm{P}$ in filter systems. These materials also contain plant nutrients and thus, may be further desirable as agricultural soil amendments (Cucarella et al., 2009). Fertiliser effect and soil structural improvements are currently being investigated at Swedish University of Agricultural Sciences (SLU). However the findings on phosphorus availability in the long term can not be made due to short duration of investigations (Ulen et al., 2013).

International research project "Ditch Filters Phase 2" funded by the Swedish Foundation BalticSea2020 and lead by Swedish Environmental Research Institute (IVL) carries out research and measures to reduced leakage from agriculture 
(Ekstrand et al., 2010). This project seeks to bind phosphorus leaching from agricultural land in midfield ditches and watercourses, using phosphorus sorbing filter materials. During Phase 2 of the project the sorption capacity of three calcium based filter materials and their ability to bind phosphorus and phosphates dissolved in agricultural runoff under field conditions in a selected sites in Sweden, Poland and Baltic States were investigated. This paper aims to overlook and evaluate the results obtained from 16 months long ditch filters investigations carried out under Lithuanian conditions.

\section{MATERIAL AND METHODS}

Site description. Selection of site for ditch filters investigations in Lithuania was based on high phosphorus concentrations in surface water bodies caused by annually application of adjacent fields with pig breeding farm wastes (slurry and liquid manure). Although the fertilization rates and terms where selected in accordance with the defined fertilization rules (no more than $170 \mathrm{~kg} \mathrm{~N} \mathrm{ha}^{-1}$ ), nonetheless the large amounts of phosphorus leaches to the surface waters: in subsurface drainage water discharged to the ditch $1.2 \mathrm{mg} \mathrm{l}^{-1}(\mathrm{TP})$ and $1.13 \mathrm{mg} \mathrm{l}^{-1}\left(\mathrm{PO}_{4}-\mathrm{P}\right)$ were determined.

Research installation was sited on the slope of the ditch (Figure 1) witch drains the arable land (approximately 358 ha) around the pig breeding farm. This ditch through the Lokauša stream discharges into the River Nevěžis which catchment characterized by high agricultural pollution and high phosphorus load (15-26 kg ha $\left.{ }^{-1}\right)$. Sandy loam soils moderate rich in humus (1.8-3.4\%) are prevailing in ditch basin. Mean phosphorus content in the plough-layer $(0-20 \mathrm{~cm})$ ranges from medium to very high $\left(120-207 \mathrm{mg} \mathrm{P} \mathrm{kg}^{-1}\right)$, in deeper layers it decreased to $44-155 \mathrm{mg} \mathrm{kg}^{-1}$, while at the depth of $1.0 \mathrm{~m}$ it was very low and ranges from 33 to $63 \mathrm{mg} \mathrm{kg}^{-1}$.
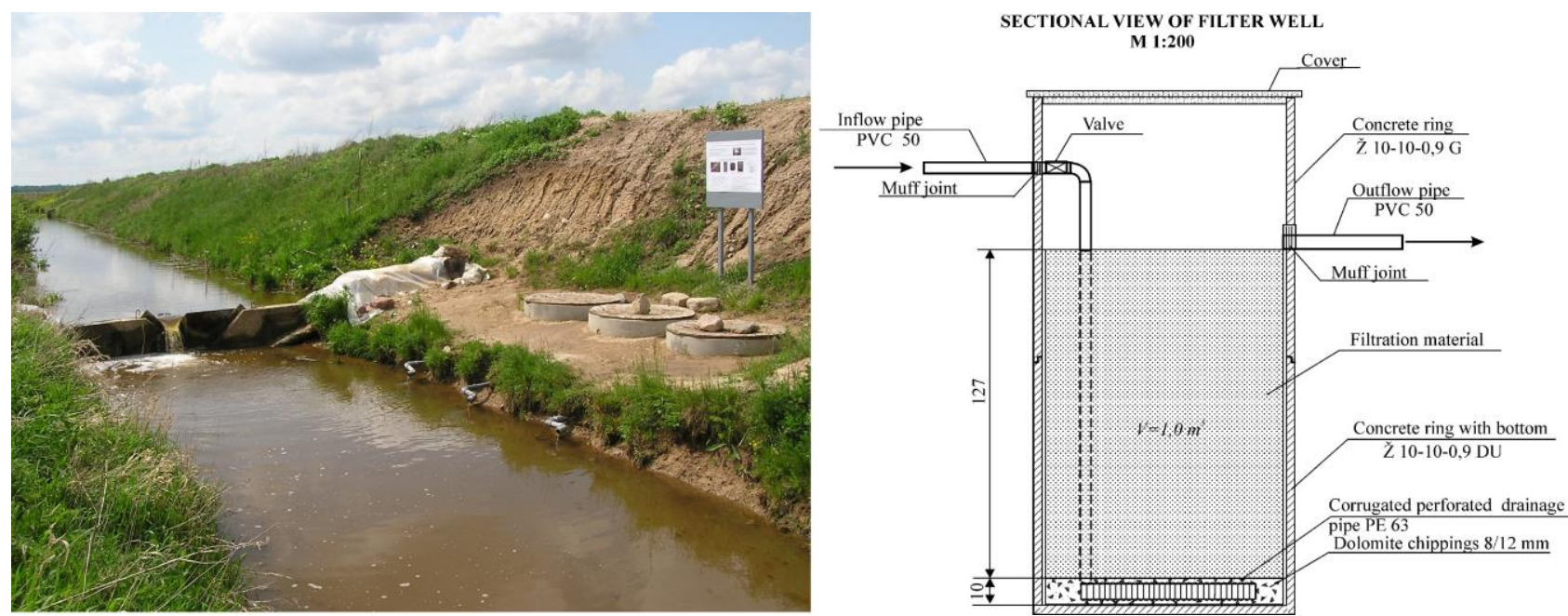

Figure 1. The overall view of the Krekenava site (on the left); sectional view of filter well (on the right).

Filter materials. The three concrete wells with different phosphorus sorbing materials were installed and three filter materials were tested regarding its phosphorus removal capacity from ditch water:

- Polonite (CaO-SiO2, CaSiO3) (calcium silicate-based material used for absorption and recycling of phosphorus);

- Filtralite- $P$ (fine grained filter material, with a large surface area and a high capacity for phosphorus removal developed using clays and natural additives. It contains $63 \% \mathrm{SiO}_{2}, 17 \% \mathrm{Al}_{2} \mathrm{O} 3,7 \% \mathrm{Fe}_{2} \mathrm{O}_{3}, 4 \% \mathrm{~K}_{2} \mathrm{O}, 2 \% \mathrm{CaO}$ and $2 \% \mathrm{Na}_{2} \mathrm{O}$ );

- Granulated blast furnace slag (Swedish trade name is the Hyttsand) (byproduct of steelmaking, it is largely limestone or dolomite which has adsorbed phosphate from the iron ore being smelted. The main components of blast furnace slag are $\mathrm{CaO}(30-50 \%), \mathrm{SiO}_{2}(28-38 \%), \mathrm{Al}_{2} \mathrm{O}_{3}(8-24 \%)$, and $\mathrm{MgO}(1-18 \%)$.

- Sampling frequency. The phosphorus reduction capacity was conducted using water quality monitoring before and after the filter installations. Monitoring period lasts for 16 months: from 2012-12-28 to 2014-05-12. 77 sampling occasions were carried out from January 2013 to May 2014, this includes in total 308 samples. The water level at the Thompson triangular overflow weir (measured continuously using e+Water L sensor/logger as well as water discharge from each filter well (measured by volumetric way at each sampling occasion) was noted. Generally water sampling was done once a week. Dates of sampling were dependent on the water level in the drainage ditch - at lower water levels, sampling was at least once a week, at the higher - two times per week. For the periods after heavy rainfall and flow peaks samples were taken twice per day, for three consecutive days. Sampling was occasionally not possible due to flooded filter wells outlet pipes during spring thaw.

Analysis and calculations. Chemical analyses were carried out in accredited Chemical analytical laboratory of Aleksandras Stulginskis University, Lithuania. Water samples were analysed for Total Phosphorus (TP) and Phosphate Phosphorus $\left(\mathrm{PO}_{4}-\mathrm{P}\right)$. In total 616 water analyses were performed during the reporting period. Concentrations were determined by the spectrometric method with FIA Star 5012 system analyser according to the water quality investigation standards (LAND 58:2003).

The reduction of phosphorus in filter materials was calculated as a ratio of the average phosphorus concentration in the effluent water $\left(C_{\text {out }}\right)$ by the average of the phosphorus in the corresponding incoming water $\left(C_{i n}\right)$ as follows: 


$$
R_{(\%)}=100\left(1-C_{\mathrm{out}} / C_{\mathrm{in}}\right)
$$

The hydraulic residence time $(t)$ in ditch filters was calculated using equation (Reed et al. 1995):

$$
t=W n / Q
$$

where $W$ - filter volume, $\mathrm{m}^{3}$ (in our case $W=1 \mathrm{~m}^{3}$ ); $n$ - porosity of filter media, in percent, expressed as a decimal; $Q$ - the average flow through the filter, $\mathrm{m}^{3} \mathrm{~h}^{-1}$.

\section{RESULTS}

Analysis showed that the main part (approximately $88 \%$ ) of total phosphorus in ditch water consisted of phosphate phosphorus (Figure 2). In many cases $(37 \%) \mathrm{PO}_{4}-\mathrm{P}$ amounted more than $90 \%$ of TP. Only during the spring thaw due to the surface water inflow to the ditch the proportion of $\mathrm{PO}_{4}-\mathrm{P}$ was relatively lower about 55-65\% of TP. The period from June to October must be excluded too, because the large part of TP consisted of organic phosphorus compounds.

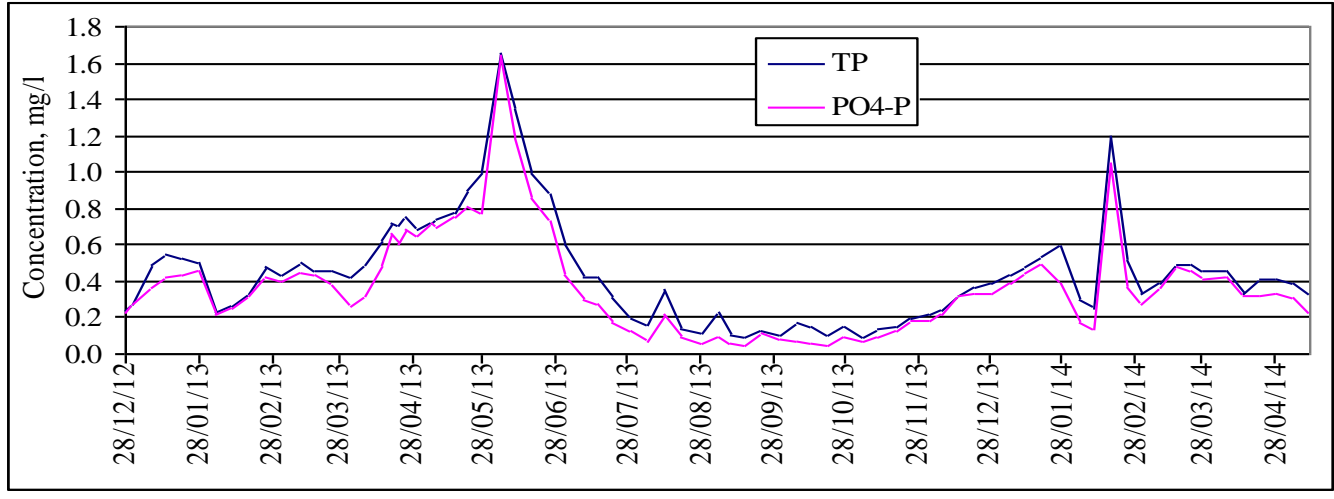

Figure 2. The concentrations of total phosphorus (TP) and phosphate phosphorus $\left(\mathrm{PO}_{4}-\mathrm{P}\right)$ in ditch water throughout the period December 28, 2012 - May 12, 2014

The first peak of total phosphorus concentrations in the ditch as well as in the outflow from the ditch filters was observed in the first half of June: it reached $1.65 \mathrm{mg} \mathrm{l}^{-1}$ in the ditch and accordingly $1.13,1.48$ and $1.19 \mathrm{mg}^{-1}$ in the outflow from filters (Figure 3). In spring of 2014, the flooding was slighter because of the sheet snow cover which has been melted much earlier because of warm weather. Due to the low surface runoff phosphorus concentrations in the ditch water were lower than in the spring of 2013 and reached only $1.20 \mathrm{mg} \mathrm{l}^{-1} \mathrm{TP}$ and $1.05 \mathrm{mg} \mathrm{l}^{-1} \mathrm{PO}_{4}-\mathrm{P}$. The outflow pipes were frozen for the time, therefore filters sorption capacity could not be determined during the peak flow.
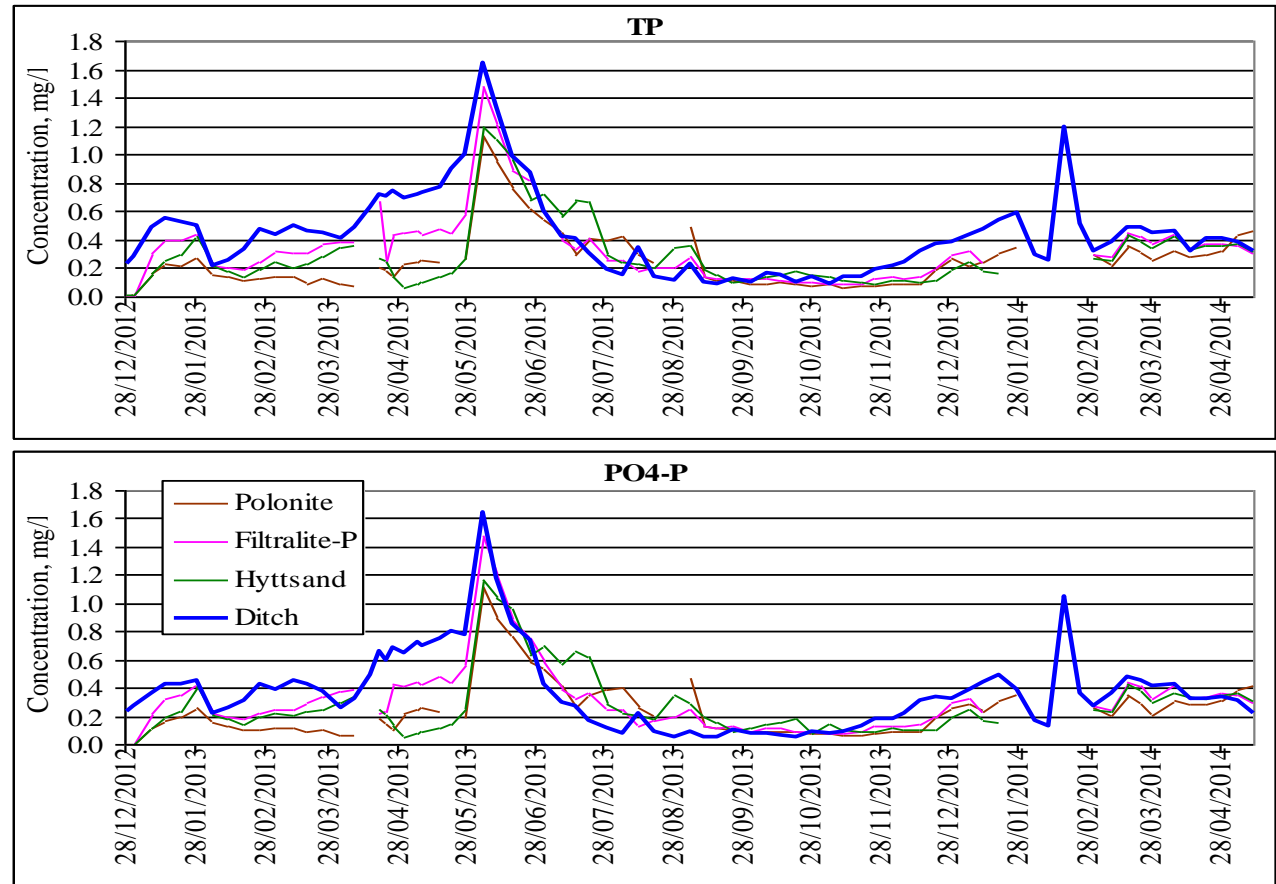

Figure 3. Variation of phosphorus concentrations in the ditch water and the outflow from different filter materials 
The phosphorus concentrations in ditch water above the dam and in filters outflow were tested by estimation of data variation ( $F$-Test for Variances) and $t$-Test for means (Table 1$)$. Significant differences in means were determined at $p<0.05$ and $p<0.01$. The results show that mean concentrations of TP in the outflow from all tested filter materials differed considerably from those in ditch water.

Table 1. The comparison of mean concentration of total and phosphate phosphorus $\left(\mathrm{mg}^{-1}\right)$ calculated during monitoring period (January 2013 - May 2014).

\begin{tabular}{l|l|l|l|l}
\hline \multirow{2}{*}{ Parameters } & \multicolumn{4}{|c}{ Sampling place } \\
\cline { 2 - 5 } & Ditch & F-1 (Polonite) & F-2 (Filtralite- $P)$ & F-3 (Hyttsand) \\
\hline $\mathrm{TP}$ & 0.446 & $0.253^{* *}$ & $0.334^{*}$ & $0.287^{* *}$ \\
\hline $\mathrm{PO}_{4}-\mathrm{P}$ & 0.374 & $0.236^{* *}$ & 0.315 & $0.268^{*}$ \\
\hline
\end{tabular}

$n=76 ; *$ statistical differences at $p<0.05 ; * *$ statistical differences at $p<0.01$

The mean concentration of $\mathrm{PO}_{4}-\mathrm{P}$ in water percolated via Polonite was significantly less $(p=0.01)$ (by about $37 \%)$ in comparison with concentration in ditch water. Slightly lower but statistically significant $(p=0.05)$ difference (by about $28 \%$ ) was estimated between $\mathrm{PO}_{4}-\mathrm{P}$ concentration in outflow from Hyttsand filter and ditch water. The maximum mean $\mathrm{PO}_{4}-\mathrm{P}$ concentration was estimated in the outflow from Filtralite- $P$ filter. It differed only about $16 \%$ from concentration in ditch water.

The retention efficiency of tested filter materials varies widely during the reporting period (Figure 4). The leakage of phosphorus was observed at certain times for all three tested filter materials. Especially reduction capacity drops down in the summer time. This tendency, when phosphorus concentrations in filters outflow were higher than in the ditch, persisted there about until the middle of November and lasts for 18 weeks. When the weather became cool the capacity of filters to retain phosphorus was regenerated. However, at the end of monitoring period (May 2014) phosphorus release from ditch filters starts again. So, three stages can be distinguished: first half-year when filters reduction capacity was at most, second stage when phosphorus release from filters takes place and regeneration stage when filters reduction capacity was renewed. First stage lasts for 24 weeks (till July, 2013), second - for 12 weeks (till October, 2013) and third - 24 weeks (till May, 2014).

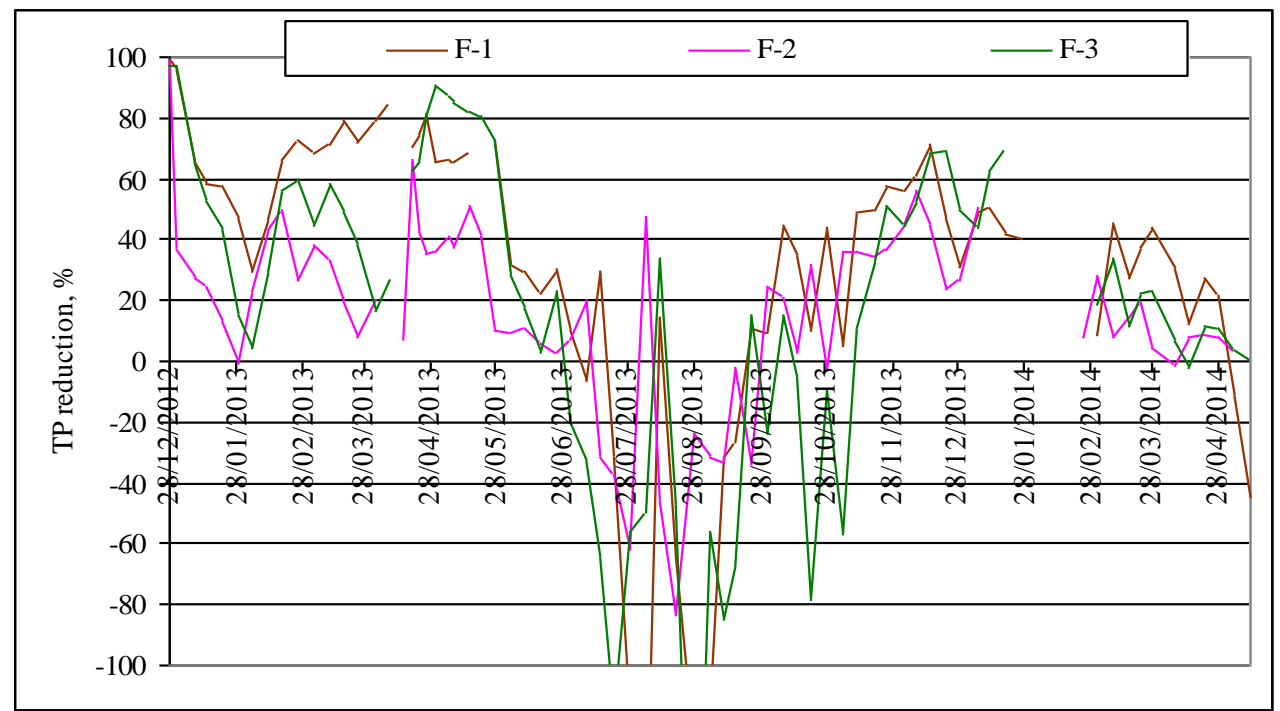

Figure 4. TP reduction capacity (\%) of different filter materials entire observation period (December 2012 - May 2014) (F-1 Polonite; F-2 - Filtralite-P; F-3 - Hyttsand).

The filter material Polonite was distinguished by highest reduction of TP capacity (57\% on average) in the first stage. Slightly less reduction by $49 \%$ was determined using Hyttsand and the least $(26 \%)$ using Filtralite-P. Reduction capacity of phosphate phosphorus was a few percentage points lower at this time: Polonite - $52 \%$, Hyttsand - $44 \%$ and Filtralite-P $-20 \%$ on average.

However, phosphorus retention in filters decreased almost to a minimum in early February 2014 when the lowest concentrations of phosphorus in ditch water were determined $\left(0.22-0.25 \mathrm{mg} \mathrm{l}^{-1}\right)$ and during the spring thaw. Extremely sensitive to changes in phosphorus concentrations in the ditch were filter materials Filtralite-P and Hyttsand. This is confirmed by a regression analysis of the first half-year monitoring data (Bastiene, 2013). TP and $\mathrm{PO}_{4}-\mathrm{P}$ concentration in the outflow from Polonite and Filtralite- $P$ filters have a strong linear relationship $(r=0.85-0.92)$ with phosphorus concentration in inflowing water, however Hyttsand filter moderately response to inflow concentrations $(r=0.68-0.73)$.

Unfortunately the last results of the first stage show unexpected decrease of phosphorus retention capacity of all filter materials. Moreover, higher phosphorus concentrations in filters outflow in comparison with inflow water were measured at the end of June, 2013. Highly variable filter discharges due to clogging inlet pipe perforation and periodical flushing greatly affected the water residence time which determines the efficiency of phosphorus retention: when the 
flow from filter wells was lowest, the hydraulic residence time was highest and vice versa. At moderate outflow $\mathrm{Q}=0.10-0.16 \mathrm{~m}^{3} \mathrm{~h}^{-1}$, water residence time in the wells ranges from 5.5 to 10 hours.

Regression analysis between phosphorus concentrations in filters outflow and filters discharge during first stage indicates that only Polonite filter have moderate linear relationship $(r=0.62)$, however, other tested filter materials (Filtralite-P and Hyttsand) show second order polynomial relationship $(r=0.69-0.93)$. Exceptionally strong relationship was established in the case of Hyttsand filter $(r=0.93)$.

So, can be concluded that sudden decrease filters reduction capacity at the end of first stage cannot be completely explained neither by reduction of filter discharges nor by phosphorus concentrations in ditch water. It is clear that the most likely cause is the clogging therefore flushing of filter system should be done once again and followup monitoring should be carried out.

The later observations during second stage of ditch filters operation have shown that Phosphorus concentrations in filters outflow frequently exceeded the ones in ditch water. Especially the large quantities of precipitation during heavy rainfall in summer and relatively low concentrations in the ditch necessitated the increase of phosphorus emission from filters.

The results gained from third stage of ditch filters operation show that filters reduction capacity was regenerated only partly. For example, during the first stage Polonite reduced TP concentration by about $61 \%$, whereas during third stage only by about $35 \%$, Hyttsand -53 and $32 \%$ respectively, Filtralite- $P-31$ and $24 \%$. PO4-P reduction declined from 60 to $26 \%$ (Polonite), from 49 to $25 \%$ (Hyttsand) and from 27 to $15 \%$ (Filtralite- $P$ ).

It was calculated that during the reporting period (January 2013 - May 2014) ditch filters adsorbed about 96-208 g $\mathrm{TP}$ and 20-124 $\mathrm{g} \mathrm{PO}_{4}-\mathrm{P}$ in total (the quantities released from filters during the second stage were rejected) (Figure 5).
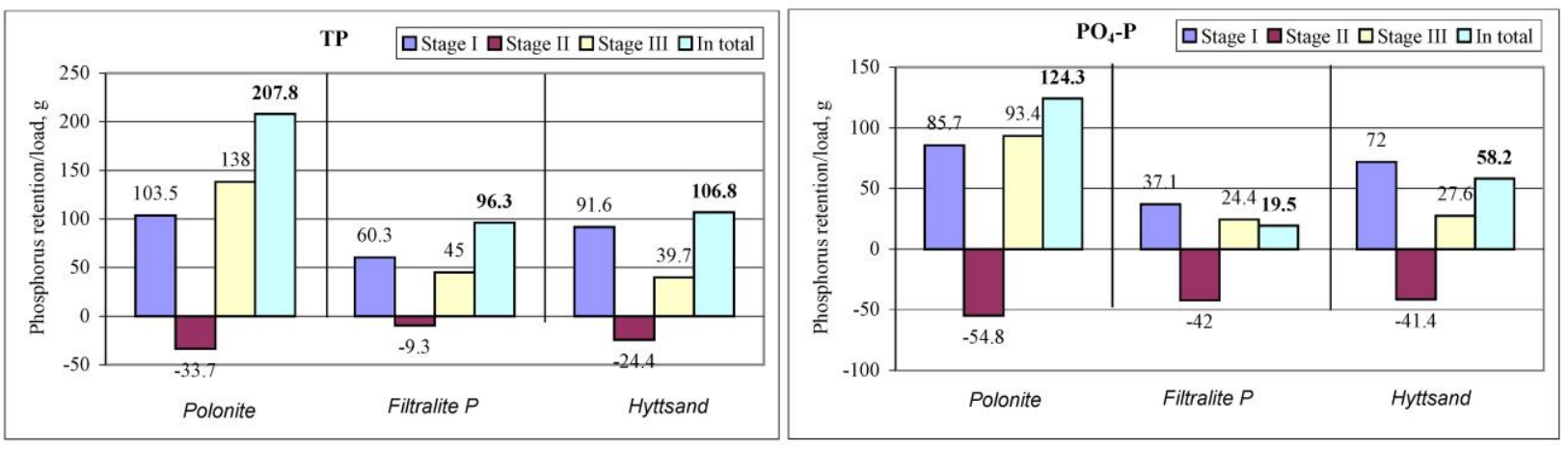

Figure 5. Phosphorus retention/ leaching (g) during the distinct measurement stages and in total

\section{DISCUSSION AND CONCLUSIONS}

The results of the project "Measures against the leakage of phosphorus from agricultural land - ditch dams and ditch filters Phase 2" shows that all the three tested filter materials, Polonite, Filtralite P and Hyttsand separate phosphorus from agricultural runoff. The results obtained in Lithuania show that mean concentrations of total phosphorus in the outflow from all tested filter materials differed significantly from those in ditch water. However, the efficiency of tested filter materials varied considerably between the materials and the various measuring stations in different countries. Based on the results obtained in Poland can be stated that low concentrations of phosphorus and phosphates in the watercourse that supply water to the experimental station, resulted in low or medium efficiency of all three tested filter materials (Swedish..., 2014). This is evidenced by the results of Krekenava monitoring site in Lithuania too, where $\mathrm{TP}$ and $\mathrm{PO}_{4}-\mathrm{P}$ concentration in the outflow from filters have a strong linear relationship ( $r=0.85-0.92)$ with phosphorus concentration in inflow water (Bastiene and Gasiūnas, 2014). Previous results from project Phase 1 shows that the reduction capacity increases when the phosphorus concentration in the inflow water is high, however phosphorus may release from filters during periods when the incoming phosphorus concentrations are low (Ekstrand et al., 2011).

Reduction capacity of filter materials varies widely during the reporting period. In Estonia the filters worked better during the first stage of the project (until freezing in December 2013). The measurements show a worsening of reducing capacity for both total phosphorus and phosphate phosphorus for all materials and at all three monitoring stations in Sweden. The ability to retain phosphorus decreased by 7-34 percentage points at the end of monitoring period in Lithuania too. So each filter material have a different capability to retain phosphorus and vary in duration of efficient operation.

Summing-up monitoring results can be concluded that under the Lithuanian conditions calcium based filter materials according to phosphorus reduction capacity may be rated in such sequence: Polonite, Hyttsand and Filtralite$P$. In Poland the greatest efficacy showed material Polonite because of the high content of Ca, the most effective from all the tested materials bind phosphate phosphorus. In Estonia the best results were obtained from Hyttsand. At the monitoring stations in Sweden the highest reduction of TP and $\mathrm{PO}_{4}-\mathrm{P}$ showed the filter material Polonite, only a slightly lower reduction showed Filtralite P. The efficiency of filter material Hyttsand was lower than compared to Polonite and Filtralite $P$, but it was the only filtering material that exhibited almost equal reduction capabilities for all three monitoring stations in Sweden (Swedish..., 2014).

Research carried out in different countries has shown that all filter materials tested in the field conditions have shown some ability to the retention of phosphorus and water purification. Filter's reduction ability could be affected by 
phosphorus concentration in inflow water: during the periods with low inflow concentration, filters sorption capacity decreases. Therefore ditch filters are more suitable in the areas with high agricultural pollution.

Ditch filters have some advantage in comparison with other environment protective measures: small land area is required for the filter, filters increases the removal of dissolved phosphorus, filter material may be used as agricultural soil amendments when becomes saturated, phosphorus can be detained at source before entering into surface waters. The weakness of ditch filters is high filter material consumption (whereas periodical material replacement is needed) and relatively high installation costs.

To achieve good results the ditch filters should meet the necessary criteria for the design and maintenance: filter material should be prevented the from freezing in winter and from flooding during high flows, protected from clogging with suspended and organic matter, filter material must be changed timely when it becomes saturated with phosphorus and its sorption capacity decreases.

Acknowledgements. This study was financially supported by the International research project "Ditch Filters Phase 2" (IVL:s project no: 202576) funded by the Swedish Foundation BalticSea2020 and lead by Swedish Environmental Research Institute (IVL) and Water Ecosystem Recovery AB (WEREC). Agreement No. V-06-78/12 „Investigation of ditch filters for the reduction of phosphorus leaches from agricultural land in Lithuania“.

\section{REFERENCES}

1. Abu-Zreig, M., Rudra, R. P., Whiteley, H. R., Lalonde, M. N., Kaushik, N. K. 2003. Phosphorus removal in vegetated filter strips. Journal of Environmental Quality, Vol. 32, Iss. 2, pp. 613-619. http://dx.doi.org/10.2134/jeq2003.6130

2. Ballantine, D. J., Tanner, C. C. 2010. Substrate and filter materials to enhance phosphorus removal in constructed wetlands treating diff use farm runoff: A review. New Zealand Journal of Agricultural Research, Vol. 53, pp. 71-95. http://dx.doi.org/10.1080/00288231003685843

3. Bastiene, N. 2013. Evaluation of lime-based ditch filters for reduction of phosphorus loses from agricultural land. Proceedings of the International Scientific Conference "Rural Development 2013”. Vol 6, Book 3, 194-199, Lithuanian university of Agriculture.

4. Bastiene, N., Gasiūnas, V. 2014. Investigation of ditch filters for the reduction of phosphorus leaches from agricultural land in Lithuania. Proceedings of the International Scientific Conference " $2{ }^{\text {nd }}$ Baltic Water Research Platform". 14-15 October, Riga, Latvia.

5. Braskerud, B., Hauge, A. 2008. Fangdammer for partikel-og fosforrensing. Fokus, Vol. 3. Nr. 12 ss. 14. Available at http://www.bioforsk.no/ikbViewer/Content/38000/Fokus_fangdammer_web.pdf

6. Bryant, R. B., Bud, A. R., Kleinman, P. J. A., Church, C. D., Bose, S., Allen, A. L. (2011). FGD Gypsum Filters Remove Soluble Phosphorus from Agricultural Drainage Waters. World of Coal Ash (WOCA) Conference - May 9-12, 2011, Denver, CO, USA.

7. Cucarella, V., Mazurek, R., Zaleski, T., Kopeć, M., Renman, G. 2009. Effect of Polonite used for phosphorus removal from wastewater on soil properties and fertility of a mountain meadow. Environmental Pollution, Vol. 157, Iss. 7, pp. $2147-52$. http://dx.doi.org/10.1016/j.envpol.2009.02.007

8. Dobbie, K. E., Heal, K.V., Aumonier, J., Smith, K.A., Johnson, A., Younger, P. L. 2009. Evaluation of iron ochre from mine drainage treatment for removal of phosphorus from wastewater. Chemosphere, Vol. 75, pp. $795-800$. http://dx.doi.org/10.1016/j.chemosphere.2008.12.049

9. Ekstrand, S., Persson, T., Bergström, R. 2011. Dikesfilter och dikesdammar. IVL rapport B2001 ss. 81: Available at http://www.ivl.se/download/18.50a499dd132037d524e80008040/ 1321440587360/B2001.pdf

10. Ekstrand, S., Wallenberg, P., Djodjic, F. 2010. Physically based modelling of Phosphorus losses from arable land. Ambio, Vol. 39, Iss. 2, pp. 100-115. http://dx.doi.org/10.1007/s13280-010-0016-5

11. Falk Øgaard, A. 2010. Phosphate adsorption on different filter materials. p. 21. In E. Turtola et al. (ed.) Novel methods for reducing agricultural nutrient loading and eutrophication. Meeting of COST 869, Jokioinen, Finland. 14-16.

12. HELCOM 2012. Fifth Baltic Sea Pollution Load Compilation (PLC-5) Baltic Sea Environment Proceeding. No 128. Helsinki Commission.

13. Hoffmann, C. C., Kjærgaard, C., Uusi-Kämppä, J., Hansen, H. C. B., Kronvang, B. 2009. Phosphorus Retention in Riparian Buffers: Review of Their Efficiency. Journal of Environmental Quality, Vol. 38, Iss. 5, pp. $1942-1955$. http://dx.doi.org/10.2134/jeq2008.0087

14. Kirkkala, T., Ventelä, A. M., Tarvainen, M. 2012. Long-Term Field-Scale Experiment on Using Lime Filters in an Agricultural Catchment. Journal of Environmental Quality, Special Issue, pp. 410-419. http://dx.doi.org/10.2134/jeq2010.0429

15. Kjaergaard, C. 2010. Sustainable phosphorus remediation and recycling technologies in the landscape. p. 43. In E. Turtola et al. (ed.) Novel methods for reducing agricultural nutrient loading and eutrophication. Meeting of COST 869, Jokioinen, Finland. 14-16 June. MTT Sci. 10. MTT Agrifood Research Finland, Jokioinen, Finland.

16. Leader, J. W., Dunne, E. J., Reddy, K. R. 2008. Phosphorus sorbing materials: Sorption Dynamics and Physicocehmical characteristics. Journal of Environmental Quality, Vol. 37, Is. 1, pp. 174-181. http://dx.doi.org/10.2134/jeq2007.0148

17. Oates, J. A. H. 1998. Lime and limestone: Chemistry and technology, production and uses. Wiley-VCH, Weinheim. http://dx.doi.org/10.1002/9783527612024

18. Penn, C.J., Bryant, R.B. 2006. Application of phosphorus sorbing materials to streamside cattle loafing areas. Journal of Soil and Water Conservation, Vol. 61, No. 6, pp. 303-310.

19. Reed, S. C., Crites, R. W., Middlebrooks, E. J. 1995. Natural Systems for Waste Management and Treatment, 2nd ed. McGraw Hill, New York, pp. 173-284. 
20. Renman, A., Renman, G. 2010. Long-term phosphate removal by the calcium-silicate material Polonite in wastewater filtration systems. Chemosphere, Vol. 79, Iss. 6, pp. 659-664. http://dx.doi.org/10.1016/j.chemosphere.2010.02.035

21. Shilton, A. N., Elmetri, I., Drizo, A., Pratt, S., Haverkamp, R. G., Bilby, S. C., 2006. Phosphorus removal by an 'active' slag filter - a decade of full scale experience. Water Research, Vol. 40, Iss. 1, pp. $113-118$. http://dx.doi.org/10.1016/j.watres.2005.11.002

22. Søvik, A. K., Kløve, B. 2005. Phosphorus retention processes in shell sand filter systems treating municipal wastewater. Ecological Engineering, Vol. 25, Iss. 2, pp. 168-182. http://dx.doi.org/10.1016/j.ecoleng.2005.04.007

23. Swedish Environmental Research Institute (IVL). 2014. Åtgärder mot fosforläckage från jordbruksmark - dikesfilter och dikesdammar; Slutrapport FAS 2. Available at http://www.segea.se/Slutrapport_Fas2_IVL_WEREC_TP_se.pdf

24. Ulén, B., Pietrzak, S., Tonderski, K. S. (sc. eds). 2013. Self-evaluation of farms for improved nutrient management and minimised environmental impact. Handbook. Institute of Technology and Life Sciences, Falenty. Available at http://www.balticsea2020.org/english/images/Bilagor/2014\%20Guide\%20-\%20Self-evaluation\%20of\%20farms.pdf

25. Vadas, P. A., Srinivasan, M. S., Kleinman, P. J., Allen, A. L. 2007. Hydrology and ground water nutrient concentrations in ditchdrained agro-ecosystem. Journal of Soil and Water Conservation, Vol. 62, Iss. 4, pp. 178-188. 